\title{
RECENT ADVANCES IN ENVIRONMENTAL PROTECTION OF OIL POLLUTED SURFACE AND GROUNDWATER IN THE NIGERIAN CONTEXT
}

\author{
Joshua O. IGHALO ${ }^{1,2^{*}}$, Adewale George ADENIYI ${ }^{1}$, Kevin Shegun OTOIKHIAN ${ }^{3}$ \\ ${ }^{1}$ Department of Chemical Engineering, Faculty of Engineering and Technology, University of Ilorin, Ilorin, Nigeria \\ ${ }^{2}$ Department of Chemical Engineering, Nnamdi Azikiwe University, P. M. B. 5025, Awka, Nigeria \\ ${ }^{3}$ Department of Chemical Engineering, Faculty of Engineering, Edo University, Iyamho
}

\begin{tabular}{|c|c|}
\hline A R T I CLE INFO & A B S T R A C T \\
\hline $\begin{array}{l}\text { Article history: } \\
\text { Received 2020-06-23 } \\
\text { Accepted 2020-09-04 } \\
\text { Available online 2020-09-04 } \\
\text { keywords } \\
\text { Petroleum } \\
\text { Environment } \\
\text { Surface water } \\
\text { Groundwater } \\
\text { Pollution }\end{array}$ & $\begin{array}{l}\text { Over the years, Nigerian researchers in environmental engineering and chemistry have been } \\
\text { evaluating a variety of technologies for the remediation of petroleum industry polluted surface } \\
\text { and groundwater. In this mini-review, the recent advances in this regard over the past two } \\
\text { years were evaluated. This was done as an appraisal of research efforts to understand the } \\
\text { current research trend and gain a proper perspective of the required/needed future approach } \\
\text { in the research area. It was observed that most studies are still focusing on evaluating the } \\
\text { problems instead of finding actual solutions. Development of workable and novel solutions } \\
\text { are urgently needed. It can be in the form of better remediation techniques or via the } \\
\text { development of alternative technologies for utilizing the waste/pollutant materials. The paper } \\
\text { has given a clear opinion on the progress of environmental protection and sustainability in } \\
\text { the Nigerian context. The environmental regulations scenario in the country is marred by } \\
\text { malpractices and corruption more stringent policy enforcement will help in the achievement } \\
\text { of environmental protection. }\end{array}$ \\
\hline
\end{tabular}




\section{INTRODUCTION}

There has been a long history of environmental problems in the Nigerian petroleum industry both in the domain of air, water, soil and noise pollution (Ogri, 2001; Ighalo and Adeniyi, 2020). As far back as 1985 during the early years of the Nigerian petroleum industry, environmental problems have always been well documented (Odeyemi and Ogunseitan, 1985). There have been also other evaluations in 2001 (Ogri, 2001), 2004 (Orubu et al., 2004) and 2013 (Ite et al., 2013). A lot of blame has been going to the oil companies and government regulations and policies have so far been ineffective (Kadafa, 2012).

Most of the pollution problems are located in the Niger delta region of Nigeria where most of the oil facilities are located (Aghalino and Eyinla, 2009). In previous assessments, the presence of pollutants such as oil, grease, hydrocarbons and heavy metals have been established in surface water and also in groundwater in some cities in Nigeria such as Ibadan (Adewuyi and Olowu, 2012), Warri (Aremu et al., 2002; Adewuyi et al., 2011), Port Harcourt (Ayotamuno et al., 2006; Amala, 2018), Oghara (Akporido, 2018), Ibeno (Inyang et al., 2018), Benin (Owamah, 2013), Bight of Bonny (Williams, 2007), Ogoni (Happy, 2018) and a host of other southern cities. All these pollutants have their origin from the processes involved in producing, refining and distributing petroleum and its products and by-products in Nigeria.

Over the years, researchers have evaluated the utilisation of plants and microorganisms for the remediation and treatment of polluted water (Ojumu et al., 2005; Adebusoye et al., 2007). Organisms such as Alcaligenes, Acinetobacter, Corynebacterium, Bacillus, Flavobacterium, Pseudomonas and Micrococcus have been evaluated (Okerentugba and Ezeronye, 2003; Ojo, 2006; Adebusoye et al., 2007). Foreign researchers have however developed more interest in utilising nanoadsorbents and biosorbents (Brandão et al., 2010; Franco, Cortés, et al., 2014; Franco, Nassar, et al., 2014) for removing petroleum hydrocarbons and oils from polluted aqueous solutions. Haven well established the premise of poor surface and groundwater in southern Nigeria (Omo-Irabor et al., 2008), much research effort has been made to remedy the situation.

In this mini-review, the recent advances in the environmental protection of surface and groundwater have been evaluated in terms of the Nigerian petroleum industry scenario. The timeline is focused on the most recent studies within the two years. This is done as an appraisal of research efforts to understand the current research trend and elucidate potential future perspectives in this research area.

\section{EVALUATION OF RECENT RESEARCH EFFORTS}

Akporido (2018) evaluated the effect of petroleum product spillage in the quality of water in the Benin-ethiope river at Oghara, Delta state. He collected fluvial samples twice per year for two years during the wet and the rainy season. He observed that the level of most of the pollutants parameters is higher than for the control area. The quality of the water in the study areas was considered as very low and it was put forward that the water is not fit for drinking. Amala (2018) investigated petroleum-degrading bacteria in water and sediments in a creek in Port-Harcourt, Nigeria. The counts of heterotrophic bacteria and petroleum degrading bacteria were determined by serial dilution and plating on nutrient agar. The bacteria isolated were Bacillus sp, Pseudomonas sp., Corynebacterium sp., Acinetobacter sp., Alkaligenes sp., Escherichia coli, Micrococcus, Klebsiella sp. and Flavobacterium sp. It was suggested that the increased count of petroleum degrading bacteria is due to the large amounts of chemicals and pollutant hydrocarbons disposed into the creeks.

Inyang et al. (2018) evaluated the amount of hydrocarbon in surface water and sediments at Ibeno, Nigeria. A random sampling at five different points was done and analysed by gas chromatography (GC-FID) technique. Their findings revealed evidence of oil contamination of the water. It was suggested that epidemiological studies on the indigenous people of the area be conducted to determine the health implications of the findings. Oil fingerprinting to identify pollution sources was also recommended. Ekperusi et al. (2018) reviewed the used water lettuce (Pistia stratiotes) for the phytoremediation of petroleum polluted waters. Though the plant has been effectively used for phytoremediation over the years, it was opined that investigations have not been carried out to elucidate the effectiveness of the species in this regard.

Ogolo et al. (2018) evaluated the effect of gas flaring on the quality of rainwater in rural communities for that have oil wells located in them in the niger delta region of Nigeria. About $38 \%$ of the collected rainwater sample were below WHO standards for rainwater quality in terms of $\mathrm{pH}$, turbidity and nitrite content. $70 \%$ of the water collected did not meet the standards for drinking water quality. The flaring of gas was established to be the major source of rainwater pollution.

The reduction and/or termination of flaring was recommended. Happy (2018) studied the environmental effect of heavy metals in Ogoni land. They observed that determining the heavy metal content of sediments at the water bed is a viable way of evaluating the number of heavy metals as they are xenobiotic. Analysis of samples collected from 5 Ogoni communities revealed that the heavy metal Barium was highest. This was due to the utilization of barium sulphate to increase the density of the drilling fluid during drilling operations. High barium content can lead to diarrhea, vomiting, difficulties in breathing, abdominal cramps, increased or decreased blood pressure, muscle weakness and numbness around the face.

Uba et al. (2018) studied the bioremediation of petroleum pollutants using several strains of marine bacteria. All the nine strains of the marine bacteria were fully characterized phylogenetically and molecularly and they belong to the genera: Alcaligenes, Providencia, Brevundimonas, Serratia, Myroides, and Bacillus. It was observed that the screening operation for the indigenous bacterial from the three studied locations resulted in the isolation of nine out of fourty eight (9/48) potent isolates. It was also established that the isolates show multiple degradations and resistance potentials on 
pyrene, xylene, other petroleum products, anthracene and heavy metals. Uba (2019) proceeded further from the previous study (2018), to investigate the bioremediation of aromatic hydrocarbons using the same nine strains. The degradation was observed to be plasmid-mediated. From the study, it was shown that isolated bacteria such as Serratia marcescens could significantly degrade low and high molecular weights aromatic hydrocarbons.

Waste lubricating oils are a major pollutant of surface water in Nigeria and is generated from the use of petroleum byproducts. To prevent its disposal into surface waters, Adeniyi et al. (2018) and Adeniyi and Ighalo (2019b) evaluated the potential of utilizing thermochemical processes to reclaim the energetic content of the waste materials utilizing an in silico platform. Adeniyi et al. (2018) predicted that pyrolysis of the liquid waste at $350^{\circ} \mathrm{C}$ could yield $77.92 \mathrm{wt} \%$ bio-oil and established the technical feasibility of the technique. Alternatively, Adeniyi and Ighalo (2019b) estimated that if used for steam reforming, every $100 \mathrm{~kg}$ of waste lubricating oil will require an optimum $1000 \mathrm{~kg}$ of water to give $317 \mathrm{~kg}$ of synthesis gas $\left(75 \% \mathrm{H}_{2}\right.$ content) and the rest as condensate water. The technical feasibility of the technique was also established.

Okoh et al. (2019) utilised electrical resistivity imaging to evaluate groundwater sub-soil pollution in Sapele. The findings of the geo-electric examination revealed five layers namely, sandy clay soil, lateritic topsoil, fine coarse sand, coarse sand and medium-coarse sand. The profiles generated from the acquired data were used to map the contamination of hydrocarbon which was delineated as an area of anomalously high interpreted resistivity.

The presence of sub-surface hydrocarbon contaminants was verified. Eze et al. (2019) used modified Ammonium sulphate for the modification of Dialium guineese seed husk to remediate oil spill polluted water by the process of biosorption. The technique of the biosorbent preparation was according to the general procedure (Adeniyi and Ighalo, 2019a) of washing drying, grinding, sieving and chemical modification by wet impregnation. The sorbent was able to remove Ó50\% of crude oil from the polluted aqueous media. This was achieved at the natural solution $\mathrm{pH}$ of 6.1 . The study also revealed an increase in removal efficacy with an increase in biosorbent dose. The usability of Dialium guineese seed husk and its modified version as low-cost biosorbents for treating oil spill polluted water was favourably established.

\section{APPRAISAL AND FUTURE PERSPECTIVES}

From this evaluation, several key observations were made as regards the advances in the environmental protection of surface and groundwater is evaluated as it regards to the Nigerian petroleum industry scenario. Most studies are still focusing on evaluating the problems.

Problem evaluation was undertaken by Akporido (2018), Amala (2018), Inyang et al. (2018), Ogolo et al. (2018), Happy (2018) and Okoh et al. (2019). However, some researchers have delved into means of finding actual solutions. Though problem finding is critical to research, developing of workable and novel solutions are also urgently needed in this area. Ekperusi et al. (2018), Uba et al. (2018), Uba (2019), Adeniyi et al. (2018), Adeniyi and Ighalo (2019b) and Eze et al. (2019) have attempted to proffer solutions to surface and groundwater pollution in a variety of ways.

This mini-review has essentially put into proper perspective that is recommended in this paper is for researchers to dig into more sophisticated technologies in developing innovative and cost-effective techniques of remediating polluted surface and ground waters in Nigeria. perspective the dearth of research interest in environmental sustainability and protection in the Nigerian context. Alternative ways of utilising would-be pollutants are needed also. The current effort seems to be grossly inadequate and progress is painstakingly slow. Furthermore, there is a need for more stringent policy enforcement. The environmental regulations scenario in the country is marred by malpractices and corruption hence effluents beyond regulatory limits are still being released. An improvement in this domain will invariably improve the quality of the of the water bodies in previously affected areas. Water has a self-cleansing ability and would overtime experience a reduction of pollution levels if more toxic effluents are not being released.

\section{CONCLUSION}

This mini-review can help tailor the research interest of the contemporary indigenous environmental engineer and chemist by opening their eyes to the current advances in environmental protection and sustainability in the domain of surface and ground waters polluted by petroleum, its products and by-products and wastes generated from its use. It is intended to rapidly disseminate knowledge about the recent progress in research on environmental protection of surface and groundwater in the Nigerian petroleum industry scenario. This is done as a wake-up call to the indigenous researchers and to help give a proper perspective of the status quo. This is the first local appraisal of its kind looking into this area within the Nigerian context. It was observed that most studies are still focusing on evaluating the problems instead of finding actual solutions.

Development of workable and novel solutions is urgently needed. It can be in the form of better remediation techniques or via the development of alternative technologies for utilising the waste/pollutant materials. The environmental regulations scenario in the country is marred by malpractices and corruption more stringent policy enforcement will help in the achievement of environmental protection. 
ADEBUSOYE, S. A. et al. Microbial degradation of petroleum hydrocarbons in a polluted tropical stream. World journal of Microbiology and Biotechnology, v. 23, n. 8, p. 1149-1159, 2007. ISSN 0959-3993.

ADENIYI, A. G.; ADEWOYE, L. T.; IGHALO, J. O. Computer Aided Simulation of the Pyrolysis of Waste Lubricating Oil using Aspen Hysys. Journal of Environmental Research, Engineering and Management v. 74, n. 2, p. 52-57, 2018.

ADENIYI, A. G.; IGHALO, J. O. Biosorption of Pollutants by Plant Leaves: An Empirical Review. Journal of Environmental Chemical Engineering, 2019a. Hydrogen production by the steam reforming of waste lubricating oil. Indian Chemical Engineer, v. 61, n. 4, p. 403-414, 2019 b.

ADEWUYI, G.; OLOWU, R. Assessment of oil and grease, total petroleum hydrocarbons and some heavy metals in surface and groundwater within the vicinity of NNPC oil depot in Apata, Ibadan metropolis, Nigeria. International Journal of Research and Revies in Applied Sciences, v. 13, n. 1, p. 166-174, 2012.

ADEWUYI, G. O.; ETCHIE, T. O.; ADEMOYEGAN, O. T. Determination of petroleum hydrocarbons and heavy metals in surface water and sediment of Ubeji river, Warri, Nigeria. Bioremediation, Biodiversity and Bioavailability, v. 5, p. 46-51, 2011.

AGHALINO, S.; EYINLA, B. Oil exploitation and marine pollution: Evidence from the Niger Delta, Nigeria. Journal of Human Ecology, v. 28, n. 3, p. 177-182, 2009. ISSN 0970-9274.

AKPORIDO, S. O. Effects Of Petroleum Products Spillages On The Water Quality Of Beninï Ethiope Fluvial System In Oghara, Nigeria. FUW Trends in Science \& Technology Journal, v. 3, n. 1, p. 141 ï 148, 2018.

AMALA, S. E. Enumeration of Total Heterotrophic and Petroleum-degrading Bacteria Counts in Water and Sediments from Diobu Creek, Port Harcourt, Nigeria. Asian Journal of Environment \& Ecology, v. 8, n. 1, p. 1-8, 2018. ISSN 2456-690X.

AREMU, D. A. et al. Heavy metal analysis of groundwater from Warri, Nigeria. International Journal of Environmental Health Research, v. 12, n. 3, p. 261-267, 2002. ISSN 0960-3123.

AYOTAMUNO, J. M.; KOGBARA, R. B.; TALEAT, M. O. Bioremediation of a petroleum-hydrocarbon polluted agricultural soil at different levels of water application in Port Harcourt, Nigeria. Journal of food agriculture and environment, v. 4, n. 3/4, p. 214, 2006. ISSN 1459-0255.

BRANDÃO, P. C. et al. Removal of petroleum hydrocarbons from aqueous solution using sugarcane bagasse as adsorbent. Journal of Hazardous Materials, v. 175, n. 1-3, p. 1106-1112, 2010. ISSN 0304-3894.

EKPERUSI, A. O.; SIKOKI, F. D.; NWACHUKWU, E. O. Phytoremediation of Petroleum Hydrocarbons in
Polluted Waters Using Pistia Stratiotes: Gaps and Future Perspective. SPE Nigeria Annual International Conference and Exhibition, 2018, Society of Petroleum Engineers.

EZE, S. I. et al. Remediation of oil spill polluted water from Niger Delta Nigeria by sorption onto ammonium sulfate modified Dialium guineense seed husk. Petroleum Science and Technology, p. 1-9, 2019. ISSN 1091-6466.

FRANCO, C. A.; CORTÉS, F. B.; NASSAR, N. N. Adsorptive removal of oil spill from oil-in-fresh water emulsions by hydrophobic alumina nanoparticles functionalized with petroleum vacuum residue. Journal of colloid and interface science, v. 425, p. 168-177, 2014. ISSN 0021-9797.

FRANCO, C. A.; NASSAR, N. N.; CORTÉS, F. B. Removal of oil from oil-in-saltwater emulsions by adsorption onto nano-alumina functionalized with petroleum vacuum residue. Journal of colloid and interface science, v. 433, p. 58-67, 2014. ISSN 0021-9797.

HAPPY, O. V. Heavy metals, risk indices and its environmental effects: A case study of Ogoniland, Niger Delta region of Nigeria. Proceedings of the International Academy of Ecology and Environmental Sciences, v. 8, n. 3, p. 172, 2018. ISSN 2220-8860.

IGHALO, J. O.; ADENIYI, A. G. A Comprehensive Review of Water Quality Monitoring and Assessment in Nigeria. Chemosphere, v. 260, p. 127569, 2020.

INYANG, S.; ALIYU, A.; OYEWALE, A. Total Petroleum Hydrocarbon Content in Surface Water and Sediment of Qua-Iboe River, Ibeno, Akwa-Ibom State, Nigeria. Journal of Applied Sciences \& Environmental Management, v. 22, n. 12, p. 1953ї 1959, 2018. ISSN 1119-8362.

ITE, A. E. et al. Petroleum exploration and production: Past and present environmental issues in the Nigeriaôs Niger Delta. American Journal of Environmental Protection, v. 1, n. 4, p. 78-90, 2013.

KADAFA, A. A. Oil exploration and spillage in the Niger Delta of Nigeria. Civil and Environmental Research, v. 2, n. 3, p. 38-51, 2012. ISSN 22245790.

ODEYEMI, O.; OGUNSEITAN, O. A. Petroleum industry and its pollution potential in Nigeria. Oil and Petrochemical Pollution, v. 2, n. 3, p. 223-229, 1985. ISSN 0143-7127.

OGOLO, N. A. et al. Rain Water Quality Evaluation in a Typical Gas Flaring Environment in the Niger Delta. SPE Nigeria Annual International Conference and Exhibition (Aug 6 - 8th, 2018), 2018, Lagos, Nigeria. Society of Petroleum Engineers.

OGRI, O. R. A review of the Nigerian petroleum industry and the associated environmental problems. Environmentalist, v. 21, n. 1, p. 11-21, 2001. ISSN 0251-1088.

OJO, O. Petroleum-hydrocarbon utilization by native bacterial population from a wastewater canal Southwest Nigeria. African Journal of 
biotechnology, v. 5, n. 4, p. 333-337, 2006. ISSN 1684-5315.

OJUMU, T. et al. Evaluation of microbial systems for bioremediation of petroleum refinery effluents in Nigeria. African Journal of Biotechnology, v. 4, n. 1, p. 31-35, 2005.

OKERENTUGBA， P.; EZERONYE， O. Petroleum degrading potentials of single and mixed microbial cultures isolated from rivers and refinery effluent in Nigeria. African Journal of Biotechnology, v. 2, n. 9, p. 288-292, 2003. ISSN 1684-5315.

OKOH, H.; EMAGBETERE, J.; IGHERIGHE, E. Investigating Groundwater and Subï Soil Pollution Using Electrical Resistivity Imaging (ERI): A Case Study of Sapele Athletic Club, Sapele Local Government Area of Delta State, Nigeria. International Journal of Innovative Scientific \& Engineering Technologies Research v. 7, n. 1, p. 44-50, 2019.

OMO-IRABOR, O. O. et al. Surface and groundwater water quality assessment using multivariate analytical methods: a case study of the Western Niger Delta, Nigeria. Physics and Chemistry of the Earth, Parts A/B/C, v. 33, n. 8-13, p. 666-673, 2008. ISSN 1474-7065.

ORUBU, C. O.; ODUSOLA, A.; EHWARIEME, W. The Nigerian oil industry: environmental diseconomies, management strategies and the need for community involvement. Journal of Human Ecology, v. 16, n. 3, p. 203-214, 2004. ISSN 0970-9274.

OWAMAH, H. I. Heavy metals determination and assessment in a petroleum impacted river in the Niger Delta Region of Nigeria. J. Pet. Environ. Biotechnol, v. 4, n. 1, p. 135-138, 2013.

UBA, B. O. Aromatic Hydrocarbons Degradation and Plasmid Profile of Marine Bacterial Isolates Obtained from Petroleum Contaminated Marine Environments of Niger Delta Nigeria. Microbiology Research Journal International, p. 1-20, 2019. ISSN 2456-7043.

UBA, B. O. et al. Multiple Degradation and Resistance Capabilities of Marine Bacteria Isolated from Niger Delta, Nigeria on Petroleum Pollutants and Heavy Metals. Journal of Advances in Biology \& Biotechnology, p. 1-17, 2018. ISSN 2394-1081.

WILLIAMS, A. B. Petroleum Hydrocarbons Accumulation Potential of Shellfishes from Littoral Waters of the Bight of Bonny, Niger Delta, Nigeria. Research Journal of Environmental Sciences, v. 1, n. 1, p. 11-19, 2007. ISSN 1819-3412. 